\title{
Reductions in expression of growth regulating genes in skeletal muscle with age in wild type and myostatin null mice
}

\author{
Jennifer C Jones, Kellie A Kroscher and Anna C Dilger
}

\begin{abstract}
Background: Genes that decline in expression with age and are thought to coordinate growth cessation have been identified in various organs, but their expression in skeletal muscle is unknown. Therefore, our objective was to determine expression of these genes (Ezh2, Gpc3, Mdk, Mest, Mycn, Peg3, and Plag/1) in skeletal muscle from birth to maturity. We hypothesized that expression of these genes would decline with age in skeletal muscle but differ between sexes and between wild type and myostatin null mice.

Results: Female and male wild type and myostatin null mice (C57BL/6J background) were sacrificed by carbon dioxide asphyxiation followed by decapitation at $d-7,0,21,42$, and 70 days of age. Whole bodies at $d-7$, all muscles from both hind limbs at d 0, and bicep femoris muscle from d 21, 42 and 70 were collected. Gene expression was determined by quantitative real-time PCR. In general, expression of these growth-regulating genes was reduced at $d 21$ compared with day 0 and $d-7$. Expression of Gpc3, Mest, and Peg3 was further reduced at d 42 and 70 compared with d 21, however the expression of Mycn increased from d 21 to $d 42$ and 70. Myostatin null mice, as expected, were heavier with increased biceps femoris weight at $d 70$. However, with respect to sex and genotype, there were few differences in expression. Expression of Ezh2 was increased at $d 70$ and expression of $M d k$ was increased at $d 21$ in myostatin null mice compared with wild type, but no other genotype effects were present. Expression of Mdk was increased in females compared to males at $d$ 70, but no other sex effects were present.
\end{abstract}

Conclusions: Overall, these data suggest the downregulation of these growth-regulating genes with age might play a role in the coordinated cessation of muscle growth similar to organ growth but likely have a limited role in the differences between sexes or genotypes.

Keywords: Ezh2, Gpc3, Mdk, Mest, Mycn, Peg3, Plagl1, Muscle growth, Myostatin

\section{Background}

As humans and animals age, growth slows and eventually stops. Organs grow until they reach mature size; however, little is known about how growth cessation is regulated and coordinated in the body. A set of growth regulating genes, which include Ezh2, Gpc3, Mdk, Mest, Mycn, Peg3, and Plagl1, has been identified that is dependent upon growth and whose expression declines with age in organs $[1,2]$. In general, when expression of these genes decreases, proliferation decreases leading to a reduction

\footnotetext{
* Correspondence: adilger2@illinois.edu
Department of Animal Sciences, University of Illinois at Urbana-Champaign,

* Correspondence: adilger2@illinois.edu
Department of Animal Sciences, University of Illinois at Urbana-Champaign, Urbana, IL 61801, USA
}

C Biomed Central

(c) 2014 Jones et al.; licensee BioMed Central Ltd. This is an Open Access article distributed under the terms of the Creative Commons Attribution License (http://creativecommons.org/licenses/by/2.0), which permits unrestricted use, distribution, and reproduction in any medium, provided the original work is properly credited. The Creative Commons Public Domain Dedication waiver (http://creativecommons.org/publicdomain/zero/1.0/) applies to the data made available in this article unless otherwise stated.

in growth. Mutations of these genes also result in reduced viability, growth abnormalities, and diseases such as rhabdomyosarcoma, a skeletal muscle cancer, and Simpson-Golabi-Behmel syndrome [3-18].

Though well characterized in organs, these genes have not been well examined in growing muscle. It is expected that expression of these genes would differ between muscle, heart, and liver because of the differences in how these tissues grow. Postnatally, muscle grows by mainly hypertrophy, an increase in cell size, and not hyperplasia, an increase in cell number [19]. In mice, muscle fiber number becomes fixed at approximately $\mathrm{d}$ 7 postnatal [20]. Hypertrophy of muscle fibers is accompanied by satellite cell activation. These cells fuse 
with existing muscle fibers to support muscle growth $[21,22]$. Without the activation of satellite cells, postnatal muscle growth and regeneration is severely inhibited. In muscle, it is known that the expression of $E z h 2, M d k$, Mest, Peg3, and Plagl1 is increased during regeneration [23-26]. In contrast, Mycn and Gpc3 have not been characterized in muscle. $M y c n$, however, increases proliferation of neural progenitor cells while Gpc3 is upregulated in the early and middle stages of liver regeneration $[27,28]$. Because 5 of 7 of these genes are known to be upregulated with muscle regeneration, it is possible that they are involved in muscle growth by increasing activation, proliferation, or differentiation of satellite cells. With age, the expression of all of these genes is expected to decline in both organs and muscle because the growth regulating functions of these genes would be less necessary once growth has ceased.

The objectives of this study were to 1 ) determine if these 7 genes were downregulated during postnatal growth of skeletal muscle, 2) determine if expression differed between male and female mice during this time period and 3) determine if expression was altered by the absence of myostatin. Myostatin null mice experience increased muscle growth due to both increased hyperplasia and hypertrophy [29] and exhibit increased satellite cell activity [30]. Furthermore, myostatin expression is decreased with increasing age in rats [31], similar to the expression patterns of genes in this study. Therefore, use of myostatin null mice as a model for altered growth to determine the influence of these genes is warranted. In general, we confirm that this set of genes is downregulated with age in skeletal muscle of mice with minimal differences between males and females. Expression of Ezh2 was increased at d 70 and expression of $M d k$ was increased at d 21 in myostatin null mice compared with wild type, but no other genotype effects were present. These results suggest that this set of genes may globally regulate the cessation of growth in skeletal muscles as well as organs, but likely do not contribute to differences in muscularity of myostatin null mice.

\section{Methods}

All procedures were approved by the University of Illinois Institutional Animal Care and Use Committee prior to beginning the experiment.

\section{Animal procedures and sample collection}

Mice from an internal C57BL/6 J colony were allowed ad libitum access to pelleted rodent chow (Teklad F6 rodent diet, Harlan, Indianapolis, IN, USA) and tap water. Room temperature was maintained at $22^{\circ} \mathrm{C}$ with a 12 hour light/ dark cycle. Male and female mice heterozygous for the myostatin null mutation were bred in monogamous pairs and litters were weaned at 21 days of age. Weaned mice were housed individually and genotyped with PCR based genotyping [29]. At 0 (birth), 21, and 42 and 70 days of age, 5 mice for each genotype by sex combination were euthanized by $\mathrm{CO}_{2}$ asphyxiation and decapitation. Only 4 male wild type mice were collected at $\mathrm{d} 70$. Pregnant dams were also euthanized by $\mathrm{CO}_{2}$ asphyxiation and decapitation 14 days after breeding (d -7) and 5 fetuses collected to represent each genotype by sex combination. At $d-7$, the entire mouse body was collected. At d 0, muscles from both hindlimbs were combined. At all other time points, biceps femoris muscles were weighed and collected. Tissues were stored at $-80^{\circ} \mathrm{C}$ until analysis.

\section{RNA Extraction and CDNA synthesis}

Total RNA was extracted using TRI-Reagent (Sigma-Aldrich, St. Louis, MO, USA) and BCP phase separation reagent (Molecular Research Center, Inc., Cincinnati, OH, USA) according to the manufacturers' protocols. RNA purity and concentration were measured using a NanoDrop 2000c spectrophotometer (Thermo Scientific, Wilmington, DE, USA). For cDNA synthesis, RNA was diluted to $500 \mathrm{ng} / \mu \mathrm{l}$ using RNase-free water and $1 \mu \mathrm{g}$ of RNA was reversed transcribed using the qScript cDNA Super Mix (Quanta Biosciences, Inc, Gaithersburg, MD).

\section{Quantitative real-time PCR}

Validation experiments were conducted according to the Applied Biosystems quantitative PCR manual (Applied Biosystems, 2004) to determine the appropriate reference gene $(\mathrm{Rn} 18 \mathrm{~S})$ and cDNA dilution. Eighteen $\mu \mathrm{l}$ of a 1:100 dilution of cDNA, $2 \mu \mathrm{l}$ of primer/probe, and $20 \mu \mathrm{l}$ of PerfeCTa ${ }^{\circ}$ qPCR FastMix Reaction Mixes (Quanta BioSciences, Inc, USA) were mixed together and plated in $18 \mu \mathrm{l}$ duplicates into a 96-well plate per reaction. Expression of Ezh2, Gpc3, Mdk, Mest, Mycn, Peg3, and Plagl1 (Table 1) was determined by quantitative real-time PCR using a StepOnePlus Real-Time PCR System thermal cycler (Life Technologies, Grand Island, NY, USA). The thermal cycler performed an initial denaturation at $95^{\circ} \mathrm{C}$ for 20 seconds followed by 40 cycles of 1 second at $95^{\circ} \mathrm{C}$ and 20 seconds at $60^{\circ} \mathrm{C}$. Expression was normalized in two separate ways. First, to compare the expression of genes with increasing age, expression was normalized to $R n 18 s(\Delta \mathrm{Ct})$ and compared to the average of 70-day-old male wild type expression $(\Delta \Delta \mathrm{Ct})$. To better visualize the influence of sex and genotype on expression, $\mathrm{Ct}$ values were normalized to $\mathrm{Rn} 18 \mathrm{~s}(\Delta \mathrm{Ct})$ and then compared within the fetal and d 0 time points to the average male wild type average of each time point $(\Delta \Delta \mathrm{Ct})$. For 21 , 42 and $70 \mathrm{~d}$ data, Ct values were normalized to $R n 18 \mathrm{~s}$ $(\Delta \mathrm{Ct})$ and then compared to the average male wild type at $21 \mathrm{~d}$ of age $(\Delta \Delta \mathrm{Ct})$. Values were expressed as a fold change $\left(2^{-\Delta \Delta C t}=\right.$ fold change) for statistical analysis. 
Table $1 \mathrm{ABI}$ primer/probe information

\begin{tabular}{llll}
\hline Gene symbol & Gene name & Gene bank reference sequence & ABI assay ID \\
\hline Ezh2 & Enhancer of zeste homolog 2 & NM_007971.2 NM_001146689.1 & Mm00468464_m1 \\
Gpc3 & Glypican 3 & NM_016697.3 & Mm00516722_m1 \\
Mdk & Midkine & NM_010784.4 & Mm00440279_m1 \\
Mest & Mesoderm specific transcript & NM_008590.1 & Mm00484993_m1 \\
Mycn & V-myc myelocytomatosis viral related oncogene, & NM_008709.3 & Mm00476449_m1 \\
Peg3 & neuroblastoma derived & NM_008817.2 & Mm01337379_m1 \\
Plagl1 & Paternally expressed 3 & NM_009538.2 & Mm00494250_m1 \\
Rn18s & Pleiomorphic adenoma gene-like 1 & NR_003278.1 & Mm03928990_g1 \\
\hline
\end{tabular}

\section{Statistical analysis}

Data were analyzed using the Proc Mixed procedure in SAS version 9.2 (SAS Institute Inc., Cary, NC, USA). The model included the fixed effects of age (when appropriate), sex, and all 2- and 3-way interactions. Data are presented as least squares means $\pm 95 \%$ confidence intervals.

\section{Results and discussion \\ Body and muscle weights}

Body and muscle weights during postnatal growth were compared between sexes and genotypes to illustrate differences in growth patterns. At day 0 and 21, body weights were similar among all genotype and sex combinations. Mice became heavier with age, and at $\mathrm{d} 70$, myostatin null mice were heavier than wild type mice within sex while males were heavier than females within genotype (Figure 1A). Bicep femoris weights were similar among all treatment groups at d 21 and 42, but myostatin null muscles were heavier than wild type at d 70 (Figure 1B). These results are similar to previous reports of body and muscle weights of myostatin null mice $[29,32]$.

\section{Expression of growth regulating genes in muscle during growth}

To determine the expression of these genes during growth, the expression of all genes in wild type male mice was analyzed in comparison to d 70 expression (Figure 2). All genes were affected $(P<0.01)$ by age with an overall decline of expression with increasing age. For all genes except Mycn, expression was not different between $\mathrm{d}-7$ and d 0; Mycn expression was reduced at d 0 compared with $\mathrm{d}-7$. In all genes, expression was reduced $(P<0.05)$ at d 21, d 42 and d 70 compared with d -7 and d 0 . Expression of Ezh2, Gpc3, Mdk, and Plagl1 did not decline further after d 21. However, the expression of Mest, and Peg3 was reduced $(P<0.05)$ at $\mathrm{d} 42$ and 70 compared with $\mathrm{d} 21$, with expression at the later time points being similar. For Mycn, expression was reduced $(P<0.05)$ at $\mathrm{d} 21$ compared with d 42 with expression at d 70 being intermediate and similar to either time point. Therefore, the results of previous experiments detailing the expression of these genes in various organs $[1,2]$ are confirmed in skeletal muscle. Expression of these genes declined with age in wild type male mice.

\section{Expression differences between sexes and genotypes}

Expression of all 7 genes was unaffected by genotype or sex at d -7 (Table 2). Similarly, at birth, expression of Ezh2, Mdk, Mycn, and Plagl1 were unaffected by sex or genotype (Table 3). Furthermore, expression of all genes was unaffected by genotype. Expression of Gpc3, Mest and Peg3 were increased in female mice compared with male mice. There were no interactions $(P<0.05)$ of sex and genotype for expression at $\mathrm{d}-7$ or birth.

Expression data from d 21, 42 and 70 were compared with the average wild type male expression at $\mathrm{d} 21$ to calculate fold changes. These data represent a consistent muscle group as opposed to the previous data that combine biceps femoris with whole hind limb or fetus (Figure 3). Expression of Mdk and Plagl1 did not decline with age from d 21 to 70 . Expression of Ezh2, Gpc3, and Peg3 were all increased $(\mathrm{P}<0.05)$ at $\mathrm{d} 21$ compared with d 42 and 70, which were similar to each other. Expression of Mest was increased $(\mathrm{P}<0.05)$ at $\mathrm{d} 21$ compared with $\mathrm{d}$ 42 and at d 42 compared with d 70. Expression of Mycn actually increased with age as expression was increased $(\mathrm{P}<0.05)$ at $\mathrm{d} 42$ and 70 compared with $\mathrm{d} 21$.

Expression of all genes was unaffected by sex. Furthermore, with the exception of $M d k$, expression was also unaffected by genotype and interactions between genotype with age or sex with age. Expression of $M d k$ was increased $(P \leq 0.01)$ at $\mathrm{d} 21$ in myostatin null mice compared with wild type, but was similar between genotypes at d 42 or 70 (Figure 3). Expression of $M d k$ was also increased $(P \leq 0.01)$ at $\mathrm{d} 70$ in female mice compared with males, but was similar between sexes at d 21 and 42 (data not shown). Expression of Ezh2 at d 70 was also increased $(P \leq 0.01)$ in wild type mice compared with myostatin 

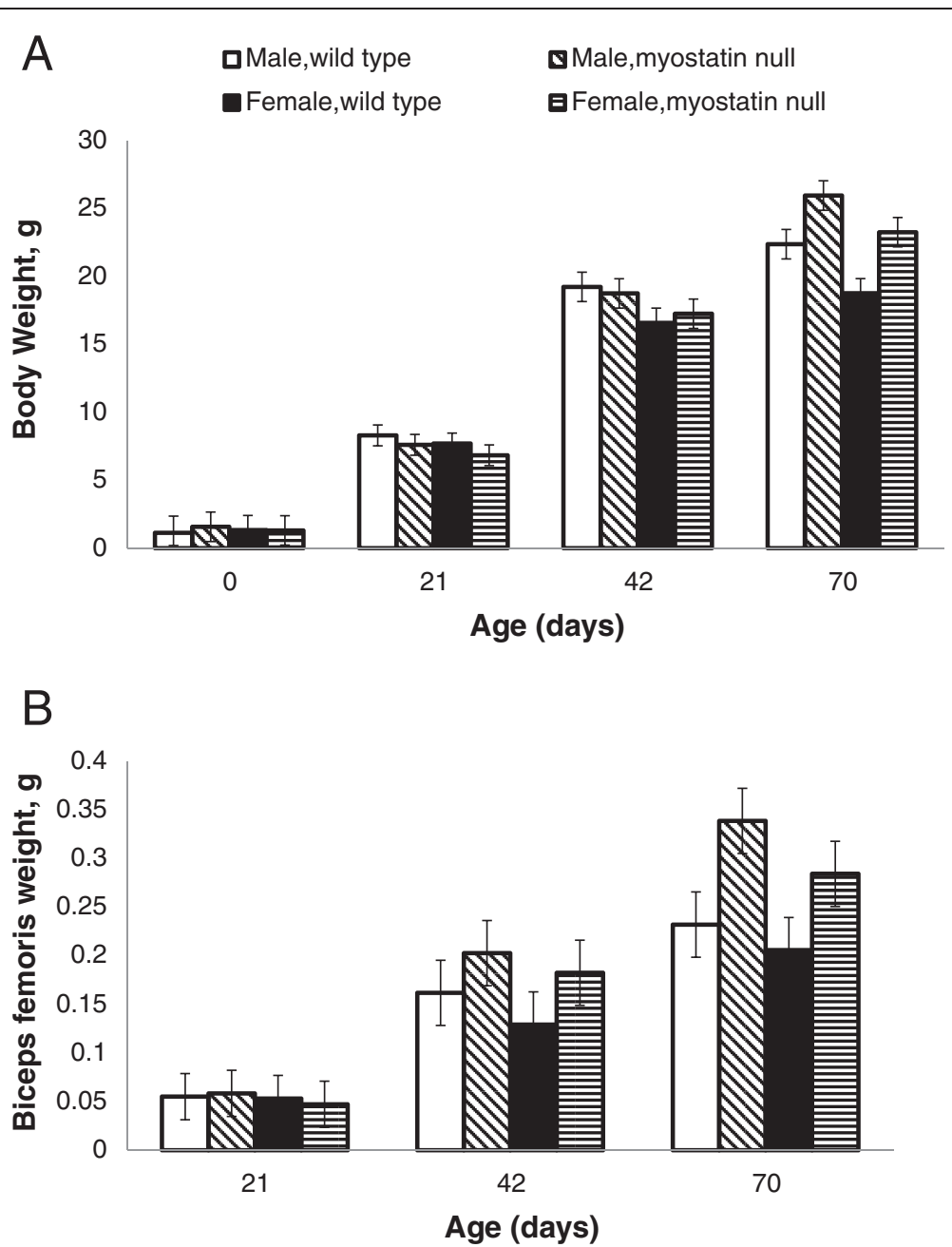

Figure 1 Body and tissue weights. Body weight (A) and muscle weight (B) of male wild type (open bars), female wild type (black bars), male myostatin null (diagonal hatched bars) and female myostatin null mice (horizontal hatched bars). Plotted values are least squares means displayed with 95\% confidence interval bars.

null. Therefore, despite differences in muscle weights at $\mathrm{d} 70$ between wild type and myostatin null mice, only the expression of two genes differed at any time point investigated and in both cases, gene expression was increased in wild type, not the more heavily muscled myostatin null mice. Therefore, these data suggest that increases in satellite cell activity and hypertrophy noted in myostatin null mice is not likely due to increased activity in these growth promoting genes.

Nevertheless, we have confirmed that this suite of genes is downregulated with age in skeletal muscle similar to other organs. Ezh2, Mdk, Mest, Peg3, and Plagl1 are known to be involved in muscle regeneration and all of the genes are overly expressed in rhabdomyosarcoma, a skeletal muscle cancer [4-8,23,24,26,33]. It is possible that these genes aid in postnatal muscle growth by activation, proliferation, or differentiation of satellite cells.
Ezh2 has an established role in satellite cell activation [24]; it can be speculated that Mdk, Mest, Peg3, and Plagl1 might have similar functions because they are also involved in muscle regeneration [23,26]. Mycn has not been well characterized in muscle, but it promotes the proliferation of neural progenitor cells and inhibits neural differentiation and, therefore, might exhibit similar functions in muscle with regard to satellite cells [27]. Given these functions, it is expected that expression of these genes would decrease with age as there is less activation, proliferation, and differentiation of satellite cells and, thus, less need for the growth regulatory functions of these genes as growth slows. In contrast, Gpc3 is thought be a negative regulator of growth such that increased expression results in reduced proliferation [28]. $G p c 3$ functions in muscle have not been identified; however, Gpc3 is involved in liver regeneration such that 

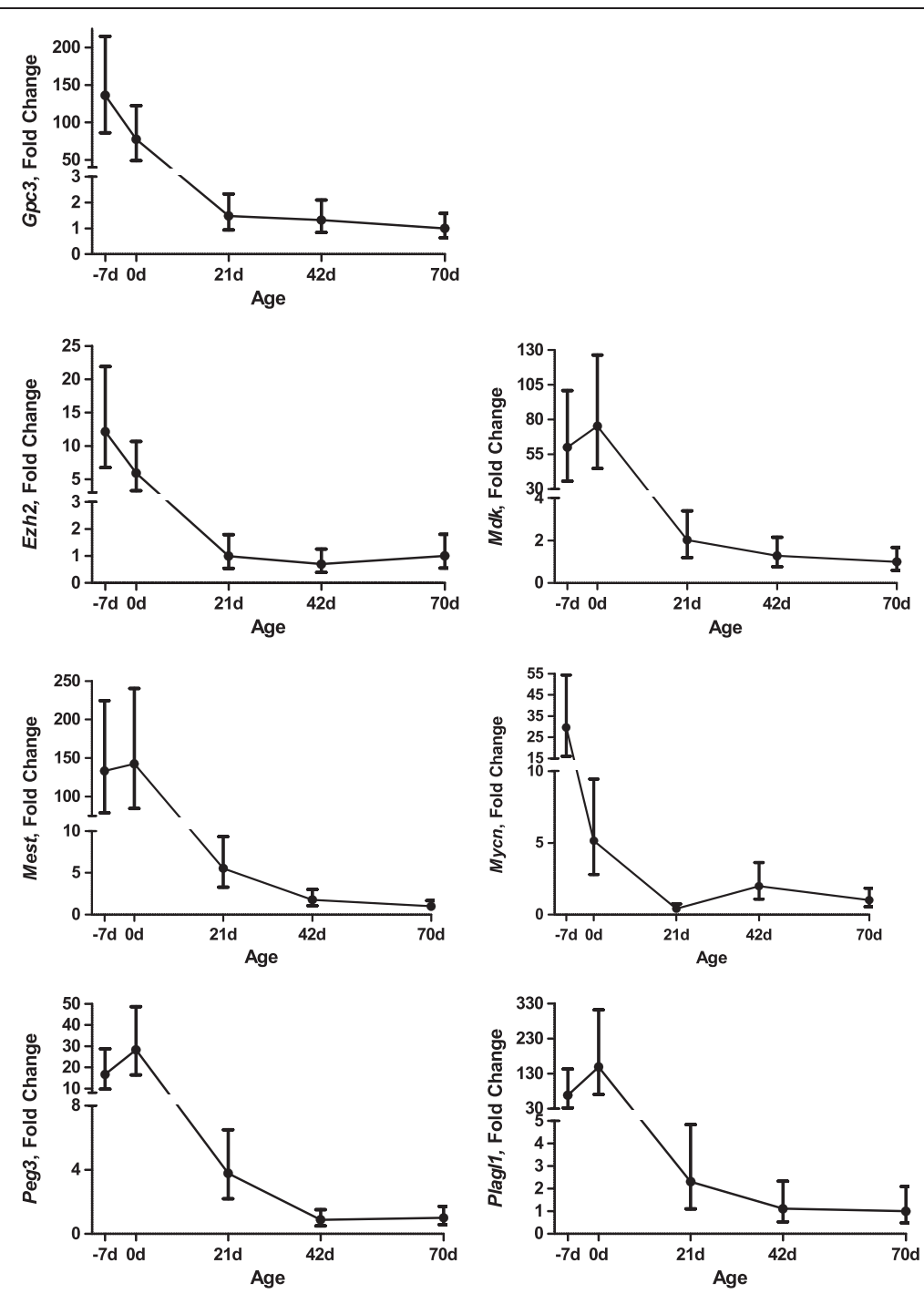

Figure 2 Expression of growth regulating genes in muscle with age. Plotted values are least squares means displayed with $95 \%$ confidence interval bars. Fold change is compared to the average wild type male 70-day-old expression.

Table 2 Effect of sex and genotype on gene expression day -7 (14 d after mating ${ }^{\text {a) }}$

\begin{tabular}{ccccccccc}
\hline & & & & & \multicolumn{3}{c}{ P-value } \\
\cline { 6 - 8 } Gene & Male & Female & Wild type & Myostatin null & Sex & Gen $^{\mathbf{b}}$ & Int $^{\mathbf{b}}$ \\
\hline Ezh2 & 0.988 & 1.249 & 1.273 & 0.969 & 0.62 & 0.56 & 0.60 \\
Gpc3 & 1.515 & 1.073 & 1.158 & 1.403 & 0.34 & 0.60 & 0.09 \\
Mdk & 1.038 & 0.927 & 0.879 & 1.094 & 0.70 & 0.47 & 0.63 \\
Mest & 1.038 & 0.904 & 1.000 & 0.938 & 0.58 & 0.80 & 0.58 \\
Mycn & 1.155 & 0.939 & 1.007 & 1.077 & 0.62 & 0.87 & 0.59 \\
Peg3 & 0.931 & 0.849 & 1.123 & 0.704 & 0.83 & 0.28 & 0.45 \\
Plagl1 & 1.327 & 0.995 & 1.095 & 1.205 & 0.58 & 0.85 & 0.37 \\
\hline
\end{tabular}

${ }^{a}$ Values are least squares means of fold changes. Fold change was compared to the average wild type male expression.

${ }^{\mathrm{b}} \mathrm{Gen}=$ Genotype, Int = Interaction of Sex and Genotype.
Table 3 Effect of sex and genotype on gene expression birth (d 0) ${ }^{\mathrm{a}}$

\begin{tabular}{ccccccccc}
\hline & & & & & \multicolumn{3}{c}{ P-value } \\
\cline { 6 - 9 } Gene & Male & Female & Wild type & Myostatin null & Sex & Gen $^{\mathbf{b}}$ & Int $^{\mathbf{b}}$ \\
\hline Ezh2 & 0.647 & 0.924 & 0.649 & 0.916 & 0.95 & 0.92 & 0.17 \\
Gpc3 & 0.853 & 1.253 & 1.114 & 0.960 & $<0.01$ & 0.21 & 0.16 \\
Mdk & 0.733 & 0.763 & 0.848 & 0.659 & 0.89 & 0.39 & 0.22 \\
Mest & 1.057 & 1.503 & 1.263 & 1.257 & 0.01 & 0.97 & 0.31 \\
Mycn & 0.908 & 1.051 & 0.935 & 1.020 & 0.55 & 0.72 & 0.26 \\
Peg3 & 0.805 & 1.076 & 1.018 & 0.851 & 0.03 & 0.17 & 0.06 \\
Plagl1 & 1.135 & 1.439 & 1.211 & 1.348 & 0.21 & 0.57 & 0.44 \\
\hline
\end{tabular}

${ }^{a}$ Values are least squares means of fold changes. Fold change was compared to the average wild type male expression.

${ }^{\mathrm{b}}$ Gen = Genotype, Int = Interaction of Sex and Genotype. 

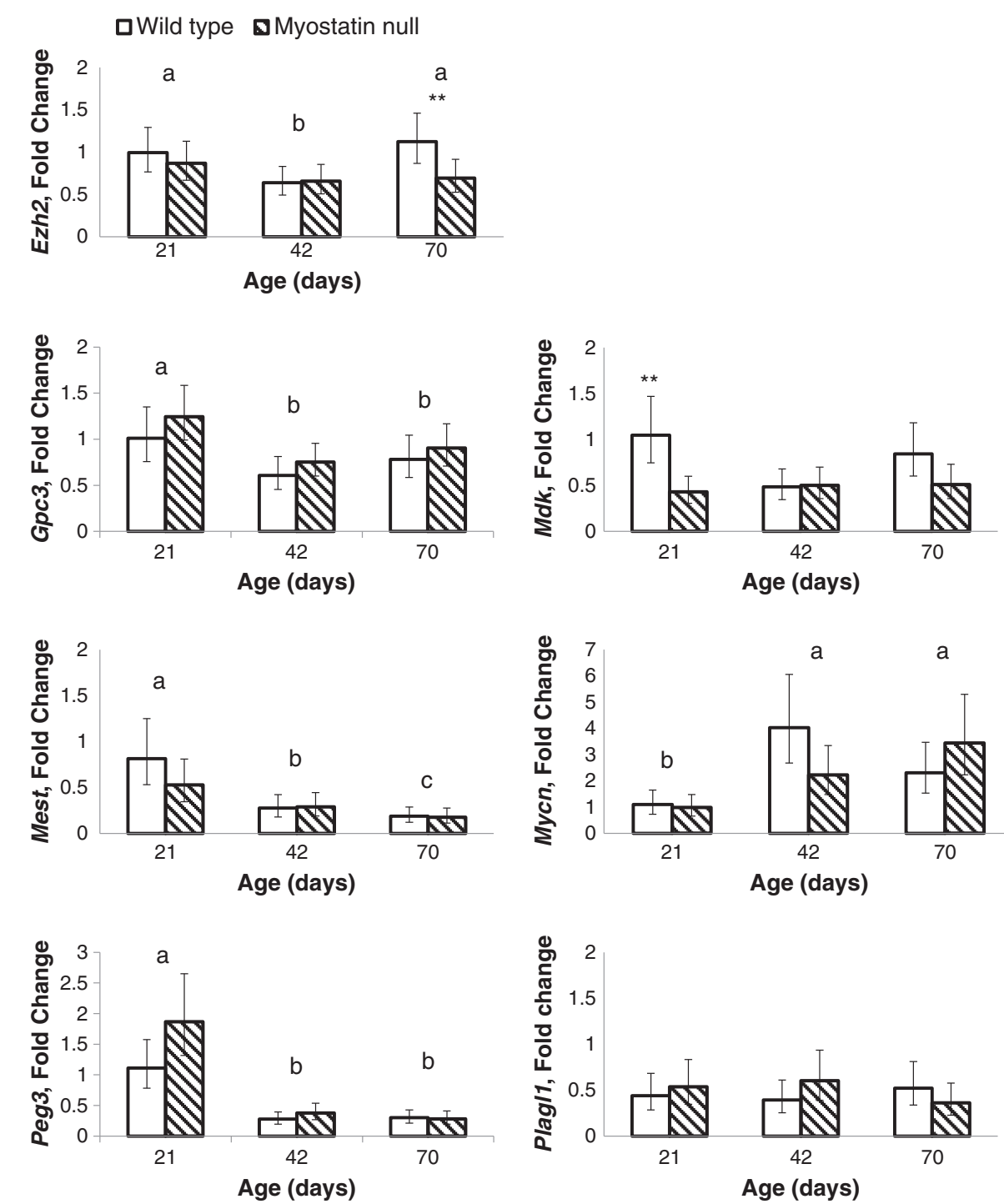

Figure 3 Comparison of expression of growth regulating genes in skeletal muscle between genotypes at postnatal days 21, 42 and 70 . Plotted values are least squares means displayed with $95 \%$ confidence interval bars of wild type (open bars) and myostatin null (hatched bars) mice. Fold change is compared to the average wild type male 70-day-old expression. Days lacking a common superscript $(a, b, c)$ are different $(P<0.05)$. **indicates that means within day are different $(P \leq 0.01)$ between genotypes.

expression peaks during the early and middle stages of the process [28]. This leads to the conclusion that Gpc3 expression might increase early in postnatal development to negatively regulate growth and proliferation, so overgrowth of organs and muscle does not occur, and decrease as growth slows because proliferation has decreased leading to less need for its regulatory functions.

\section{Conclusions}

In summary, this study examined the expression decline of 7 growth regulating genes over time in the muscle of wild type and heavily muscled myostatin null mice. Overall, expression was increased in all genes at the fetal time point or birth compared with $21 \mathrm{~d}$ of age or later. Despite differences in muscle weights between wild type and myostatin null mice, there were not widespread expression differences between genotypes, nor were there differences between sexes. Therefore, differences observed in muscle weights, especially between those of myostatin null and wild type mice, do not seem to result from differential regulation of the growth-regulating genes examined in this study. It should be noted, however, that the expression of these genes may be different in the satellite or stem cell populations of skeletal muscle compared with the skeletal muscle as a whole. Future work to differentiate the role of these genes in satellite or stem cell proliferation, differentiation and fusion with existing muscle fibers may be warranted. 


\section{Competing interests}

The authors declare they have no competing interests.

\section{Authors' contributions}

JCJ carried out the preliminary studies, established the methods, and drafted the manuscript. KAK carried out the study and performed the statistical analysis. ACD conceived the study, and participated in its design and coordination and helped to draft the manuscript. All authors read and approved the final manuscript.

Received: 3 September 2013 Accepted: 25 March 2014

Published: 28 March 2014

\section{References}

1. Lui JC, Forcinito P, Chang M, Chen W, Barnes KM, Baron J: Coordinated postnatal down-regulation of multiple growth-promoting genes: evidence for a genetic program limiting organ growth. FASEB J 2010, 24(8):3083-3092.

2. Finkielstain GP, Forcinito P, Lui JCK, Barnes KM, Marino R, Makaroun S, Nguyen V, Lazarus JE, Nilsson O, Baron J: An extensive genetic program occurring during postnatal growth in multiple tissues. Endocrinology 2009, 150(4):1791-1800.

3. Pilia G, Hughes-Benzie RM, MacKenzie A, Baybayan P, Chen EY, Huber R, Neri G, Cao A, Forabosco A, Schlessinger D: Mutations in GPC3, a glypican gene, cause the Simpson-Golabi-Behmel overgrowth syndrome. Nat Genet 1996, 12(3):241-247.

4. Ciarapica R, Russo G, Verginelli F, Raimondi L, Donfrancesco A, Rota R, Giordano A: Deregulated expression of miR-26a and Ezh2 in rhabdomyosarcoma. Cell Cycle 2009, 8(1):172-175.

5. Jin Z, Lahat G, Korchin B, Nguyen T, Zhu QS, Wang X, Lazar AJ, Trent J, Pollock $R E$, Lev D: Midkine enhances soft-tissue sarcoma growth: a possible novel therapeutic target. Clin Cancer Res 2008, 14(16):5033-5042.

6. Toffolatti L, Frascella E, Ninfo V, Gambini C, Forni M, Carli M, Rosolen A MYCN expression in human rhabdomyosarcoma cell lines and tumour samples. J Pathol 2002, 196(4):450-458.

7. Williamson D, Lu YJ, Gordon T, Sciot R, Kelsey A, Fisher C, Poremba C, Anderson J, Pritchard-Jones K, Shipley J: Relationship between MYCN copy number and expression in rhabdomyosarcomas and correlation with adverse prognosis in the alveolar subtype. J Clin Oncol 2005, 23(4):880-888.

8. Rezvani G, Lui JCK, Barnes KM, Baron J: A set of imprinted genes required for normal body growth also promotes growth of rhabdomyosarcoma cells. Pediatr Res 2012, 71(1):32-38.

9. O'Carroll D, Erhardt S, Pagani M, Barton SC, Surani MA, Jenuwein T: The Polycomb-group gene Ezh2 is required for early mouse development. Mol Cell Biol 2001, 21(13):4330-4336.

10. Nakamura E, Kadomatsu K, Yuasa S, Muramatsu H, Mamiya T, Nabeshima T, Fan QW, Ishiguro K, Igakura T, Matsubara S, Kaname T, Horiba M, Saito H, Muramatsu T: Disruption of the midkine gene ( $M d k)$ resulted in altered expression of a calcium binding protein in the hippocampus of infant mice and their abnormal behaviour. Genes Cells 1998, 3(12):811-822

11. Varrault A, Gueydan C, Delalbre A, Bellmann A, Houssami S, Aknin C, SeveraC D, Chotard L, Kahli M, Le Digarcher A, Pavlidis P, Journot L: Zac1 regulates an imprinted gene network critically involved in the control of embryonic growth. Dev Cell 2006, 11(5):711-722.

12. Chiao E, Fisher P, Crisponi L, Deiana M, Dragatsis I, Schlessinger D, Pilia G, Efstratiadis A: Overgrowth of a mouse model of the Simpson-Golabi-Behmel syndrome is independent of IGF signaling. Dev Biol 2002, 243(1):185-206.

13. Sakakima H, Yoshida Y, Yamazaki Y, Matsuda F, Ikutomo M, ljiri K, Muramatsu $\mathrm{H}$, Muramatsu T, Kadomatsu K: Disruption of the midkine gene (Mdk) delays degeneration and regeneration in injured peripheral nerve. J Neurosci Res 2009, 87(13):2908-2915.

14. Li LL, Keverne EB, Aparicio SA, Ishino F, Barton SC, Surani MA: Regulation of maternal behavior and offspring growth by paternally expressed Peg3. Science 1999, 284(5412):330-333.

15. Lefebvre L, Viville S, Barton SC, Ishino F, Keverne EB, Surani MA: Abnormal maternal behaviour and growth retardation associated with loss of the imprinted gene Mest. Nat Genet 1998, 20(2):163-169.

16. Charron J, Malynn BA, Fisher P, Stewart V, Jeannotte L, Goff SP, Robertson EJ, Alt FW: Embryonic lethality in mice homozygous for a targeted disruption of the N-myc gene. Genes Dev 1992, 6(12a):2248-2257.
17. Stanton BR, Perkins AS, Tessarollo L, Sassoon DA, Parada LF: Loss of N-myc function results in embryonic lethality and failure of the epithelial component of the embryo to develop. Genes Dev 1992, 6(12a):2235-2247.

18. Sawai S, Shimono A, Wakamatsu Y, Palmes C, Hanaoka K, Kondoh H: Defects of embryonic organogenesis resulting from targeted disruption of the N-myc gene in the mouse. Development 1993, 117(4):1445-1455.

19. Enesco M, Puddy D: Increase in the number of nuclei and weight in skeletal muscle of rats of various ages. Am J Anat 1964, 114(2):235-244.

20. White R, Bierinx A-S, Gnocchi V, Zammit P: Dynamics of muscle fibre growth during postnatal mouse development. BMC Dev Biol 2010, 10(1):21.

21. Moss FP, Leblond CP: Satellite cells as the source of nuclei in muscles of growing rats. Anat $\operatorname{Rec} 1971,170(4): 421-435$

22. Stockdale FE, Holtzer H: DNA synthesis and myogenesis. Exp Cell Res 1961, 24(3):508-520

23. Yan Z, Choi S, Liu X, Zhang M, Schageman JJ, Lee SY, Hart R, Lin L, Thurmond FA, Williams RS: Highly coordinated gene regulation in mouse skeletal muscle regeneration. J Biol Chem 2003, 278(10):8826-8836.

24. Juan AH, Derfoul A, Feng X, Ryall JG, Dell'Orso S, Pasut A, Zare H, Simone JM, Rudnicki MA, Sartorelli V: Polycomb EZH2 controls self-renewal and safeguards the transcriptional identity of skeletal muscle stem cells. Genes Dev 2011, 25(8):789-794.

25. Hu J, Higuchi I, Yoshida Y, Shiraishi T, Osame M: Expression of midkine in regenerating skeletal muscle fibers and cultured myoblasts of human skeletal muscle. Eur Neurol 2002, 47(1):20-25.

26. Sakakima H, Kamizono T, Matsuda F, Izumo K, ljiri K, Yoshida Y: Midkine and its receptor in regenerating rat skeletal muscle after bupivacaine injection. Acta Histochem 2006, 108(5):357-364.

27. Knoepfler PS, Cheng PF, Eisenman RN: N-myc is essential during neurogenesis for the rapid expansion of progenitor cell populations and the inhibition of neuronal differentiation. Genes Dev 2002, 16(20):2699-2712

28. Liu B, Paranjpe S, Bowen WC, Bell AW, Luo JH, Yu YP, Mars WM, Michalopoulos GK: Investigation of the role of glypican 3 in liver regeneration and hepatocyte proliferation. Am J Pathol 2009, 175(2):717-724.

29. MCPherron AC, Lawler AM, Lee SJ: Regulation of skeletal muscle mass in mice by a new TGF-beta superfamily member. Nature 1997, 387(6628):83-90

30. McCroskery S, Thomas M, Maxwell L, Sharma M, Kambadur R: Myostatin negatively regulates satellite cell activation and self-renewal. J Cell Biol 2003, 162(6): 1135-1147.

31. Nishimura T, Oyama K, Kishioka Y, Wakamatsu J-i, Hattori A: Spatiotemporal expression of decorin and myostatin during rat skeletal muscle development. Biochem Biophys Res Commun 2007, 361(4):896-902.

32. Dilger AC, Gabriel SR, Kutzler LW, McKeith FK, Killefer J: The myostatin null mutation and clenbuterol administration elicit additive effects in mice. Animal 2010, 4(03):466-471.

33. Thway K, Selfe J, Missiaglia E, Fisher C, Shipley J: Glypican-3 is expressed in rhabdomyosarcomas but not adult spindle cell and pleomorphic sarcomas. J Clin Pathol 2011, 64(7):587-591.

doi:10.1186/1472-6793-14-3

Cite this article as: Jones et al:: Reductions in expression of growth regulating genes in skeletal muscle with age in wild type and myostatin null mice. BMC Physiology 2014 14:3.

\section{Submit your next manuscript to BioMed Central and take full advantage of:}

- Convenient online submission

- Thorough peer review

- No space constraints or color figure charges

- Immediate publication on acceptance

- Inclusion in PubMed, CAS, Scopus and Google Scholar

- Research which is freely available for redistribution 